УДК 62-932.2

05.00.00 Технические науки

ЭКСПЕРИМЕНТАЛЬНЫЕ ИССЛЕДОВАНИЯ
ПАРАМЕТРОВ И РЕЖИМОВ
ЭЛЕКТРОТЕХНОЛОГИЧЕСКОГО
ПРОЦЕССА ОЗОНИРОВАНИЯ
ЯЙЦЕСКЛАДОВ ПТИЦЕФАБРИК

Волошин Александр Петрович старший преподаватель Кубанский государственный аграрный университет, Краснодар, Россия

Получение максимального количества суточного молодняка в значительной степени зависит от дезинфекции инкубационных яиц, которая в комплексе ветеринарно-санитарных мероприятий; проводимых в птицеводческих хозяйствах по предупреждению и ликвидации заразных болезней птиц, занимает важное место. Перспектива применения озона в промышленном птицеводстве обусловлена его преимуществами, которыми он характеризуется в сравнении с другими химическими веществами. Установлено, что озон имеет особенной способностью задерживать рост грибков на биологических субстратах, также замедляет процесс появления плесени на поверхности скорлупы яиц даже при $90 \%$ относительной влажности. При обосновании параметров и режимов электротехнологического процесса озонирования яйцескладов птицефабрик были выполнены экспериментальные исследования. После дезинфекции инкубационных яиц озоном общая бактериальная обсемененность скорлупы яиц снизилась на 99,89\%.

Относительные погрешности экспериментальных значений от теоретических составляют 7\%. В результате производственных испытаний установлены параметры качества, разработанного электротехнологического процесса озонирования яйцескладов птицефабрик: время регулирования 8 минут, динамическая ошибка $-0,9$, коэффициент перерегулирования $-4,5 \%$, обобщённый интегральный среднеквадратичный показатель $10,6 \%$. Полученные данные свидетельствуют о качественном регулировании распределения концентрации озона в яйцескладе

КЛючевЫе слова: ОЗОНАТОР, ТЕСТ-БАКТЕРИИ, СИСТЕМА УПРАВЛЕНИЯ, КОНЦЕНТРАЦИЯ ОЗОНА, ПОКАЗАТЕЛИ КАЧЕСТВА, ПАРАМЕТРЫ ЭЛЕКТРОТЕХНОЛОГИЧЕСКОГО ПРОЦЕССА ОЗОНИРОВАНИЯ

Doi: 10.21515/1990-4665-121-071
UDC 62-932.2

Engineering

\section{EXPERIMENTAL STUDY OF PARAMETERS AND MODES OF ELECTROTECHNOLOGICAL OZONIZATION OF EGG STORES IN POULTRY FARMS}

Voloshin Aleksandr Petrovich

senior lecturer

Kuban State Agrarian University, Krasnodar, Russia

Getting the maximum number of day-old chicks largely depends on the disinfection of hatching eggs. Disinfection of eggs is important in the complex of veterinary-sanitation activities carried out in poultry farms for the prevention and elimination of infectious disease in birds. The perspective of using ozone in the poultry industry is possible due to its advantages characterized in comparison with other chemicals. It was found that ozone has the special ability to retard the growth of fungi in the biological substrates, also slows the appearance of mold on the surface of the eggshell even at $90 \%$ relative humidity. When making parameters and modes of electro-ozonation process of egg store poultry farms there were carried out experimental studies. After ozone disinfection of hatching eggs, total bacterial contamination of shell eggs decreased by $99.89 \%$. The relative error of the experimental values of the theoretical amount was 7 $\%$. As a result of production tests we set quality parameters developed by the process of electroozonation egg store poultry farms: regulation time is 8 minutes, dynamic error is 0.9 , overshoot rate is $4.5 \%$, generalized integral RMS figure is $10.6 \%$. The findings suggest that there is a qualitative regulation of the distribution of ozone in the egg store

Keywords: OZONATOR, TEST-BACTERIA, CONTROL, OZONE CONCENTRATION, QUALITY, PARAMETERS OF ELECTROTECHNOLOGICAL OZONIZATION 
Озонирование, являясь эффективным способом дезинфекции, дезинсекции и дезодорирования практически любых сред, особенно воздуха и воды, активно используется на птицефабриках. Главная цель дезинфекции инкубационных яиц - уничтожение патогенных микроорганизмов, при том, что сам озон не образует вредных веществ и не влияет негативно на продукты питания. Обработанные озоном яйца лучше сохраняются, вывод молодняка увеличивается на несколько процентов. Кроме того, яйцо можно подвергнуть прямой дезинфекции озоном несколько раз: практически сразу, после снесения, перед закладкой в инкубатор и после переноса в выводной шкаф.

Значительные научные исследования, выполненные в 60-80гг. специалистами ВНИТИП, другими научными учреждениями, были обобщены в монографии И.П. Кривопишина «Озон в промышленном птицеводстве» (1988). В частности, было установлено, что концентрация

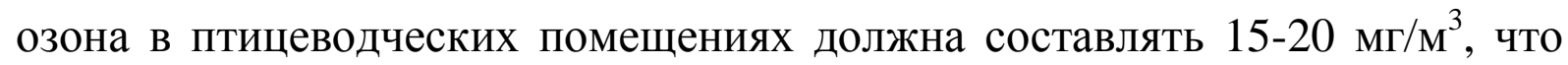
достаточно для уничтожения основных видов микрофлоры в течение 15-и минутной обработки. На этой экспериментальной основе разработаны эффективные технологии озонирования птичников и инкубаториев, пищевых и инкубационных яиц, которые успешно внедрялись на птицефабриках. Однако такие технологии не получили в своё время широкого распространения из-за отсутствия высокоэффективных и экономичных озонаторов отечественного производства. В ранних исследованиях ВНИТИП было установлено, что наибольшая эффективность озонирования отмечалась при обработке инкубационных яиц, когда уничтожается до 98\% микроорганизмов в воздухе помещения, а бактериальная обсемененность скорлупы уменьшается в 5-8 раз, при этом вывод суточного молодняка и его сохранность повышаются на несколько процентов. В действующих рекомендациях по инкубации яиц (2008г.) предлагается проводить длительное хранение инкубационных яиц в среде, 
обогащенной озоном. Яйца, уложенные в лотки, в тележках размещают в герметичном помещении яйцесклада, в котором поддерживается определённая концентрация озоновоздушной смеси.

Проведенные поисковые эксперименты на яйцескладе ООО «Птицевод» Краснодарского края показали, что существует проблема в нестабильной работе озонаторов в помещении.

Концентрация озона, создаваемая электроозонатором, в помещении яйцесклада не одинакова. Чем больше расстояние от электроозонатора, тем меньше концентрация озона, что влияет на качество обработки яиц. В свою очередь необходимо также учитывать не только расстояние от озонатора до самой удалённой точки, но и количество яиц, закладываемое в яйцесклад, так как они и в том числе поверхности помещения яйцесклада также способствуют разложению озона. Такие исследования до сих пор не проводились, поэтому целесообразно создание и обоснование параметров и режимов электротехнологического процесса озонирования яйцескладов птицефабрик.

При обосновании параметров и режимов электротехнологического процесса озонирования яйцескладов птицефабрик были выполнены экспериментальные исследования. Для проведения эксперимента была собрана лабораторная установка, которая позволяет подавать озоновоздушную смесь заданной концентрации (рис. 1). Лабораторная установка состоит из трех основных частей: электроозонатора, щита управления и датчиков концентрации озона. 


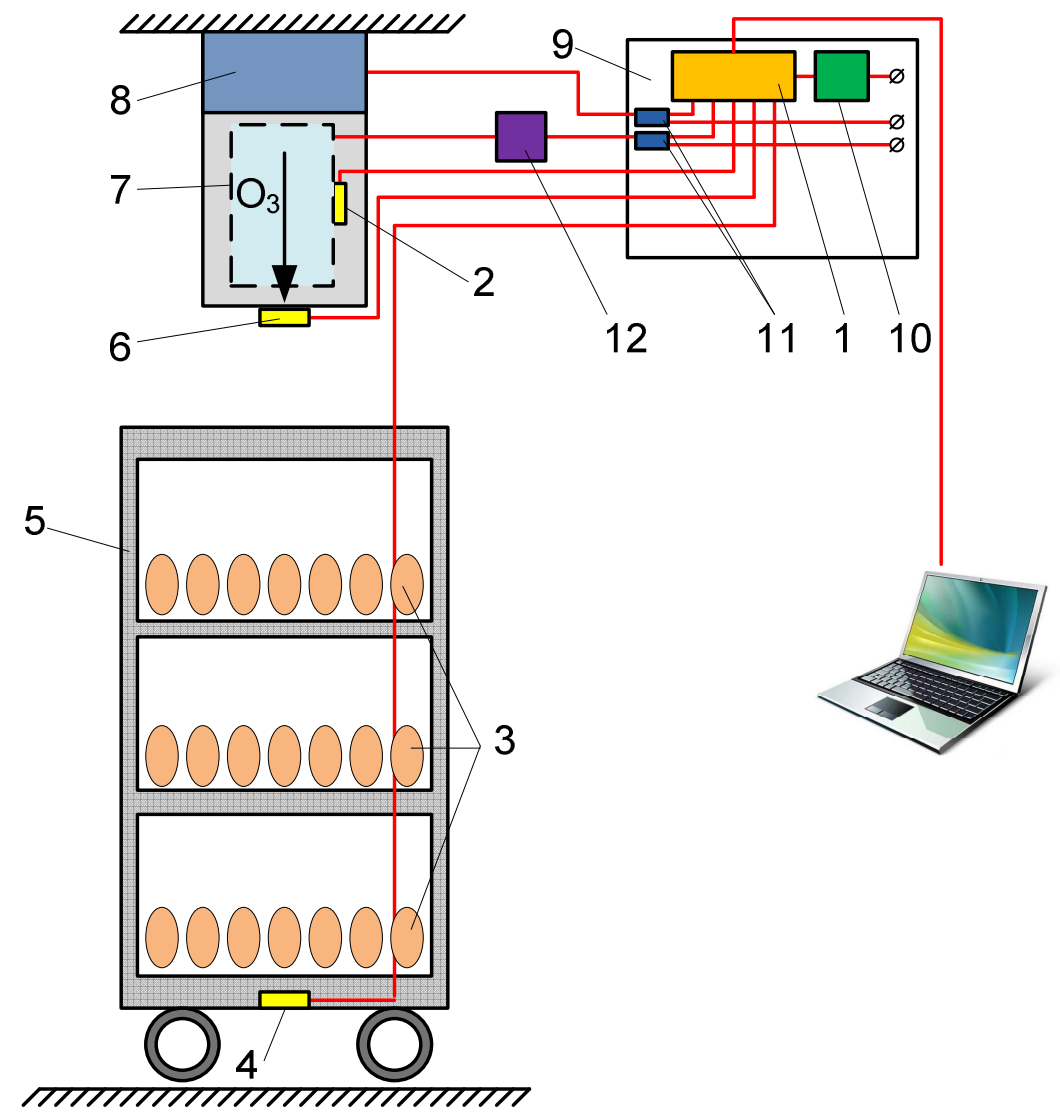

Рисунок 1 - Структурная схема лабораторной установки: 1 - регулятор; 2 датчик температуры DS18B20; 3 - яйца; 4 - второй датчик концентрации озона; 5 - контейнер для хранения яиц; 6 - первый датчик концентрации озона; 7 - разрядное устройство; 8 - вентилятор; 9 - щит управления, 10 источник питания; 11 - силовые ключи, 12 - повышающий трансформатор.

Концентрация озона измерялась газоанализатором «Циклон - 5.41». Принцип действия газоанализатора заключается в фотометрическом определении озона по собственной полосе поглощения на $\lambda=2537 \mathrm{~A}$. Газоанализатор представляет собой однолучевой фотометр, в котором функцию второго канала выполняет источник опорного сигнала. 


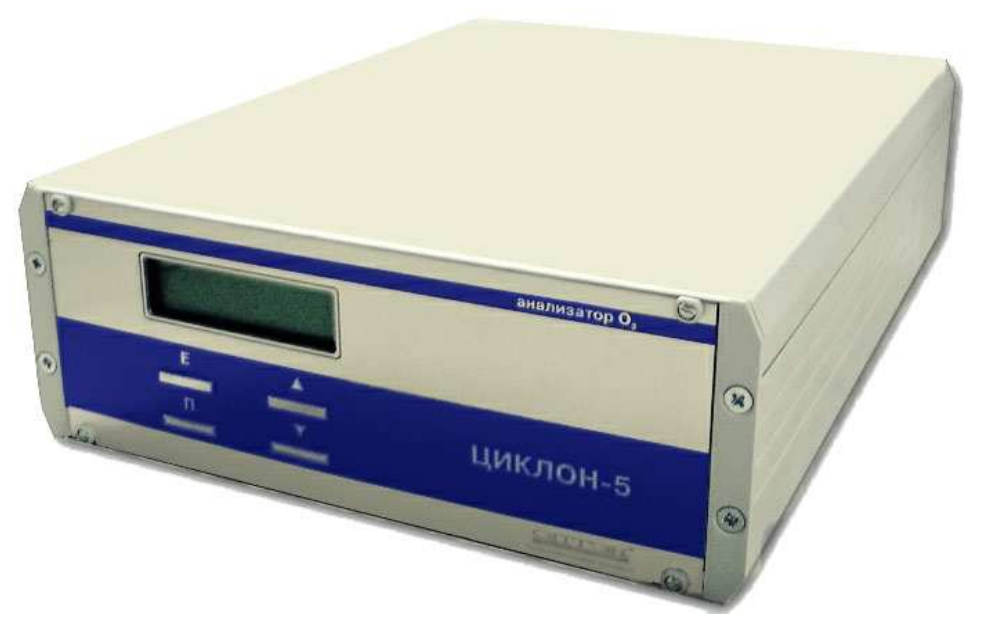

Рисунок 2 - Общий вид газоанализатора «Циклон - 5.41».

Методика определения микробной обсемененности основана на седиментационном методе исследования осажденных микроорганизмов на открытых поверхностях питательных сред, физиологического раствора или стерильных стекол.

Микроорганизмы в воздухе находятся во взвешенном состоянии. Обычно они фиксированы на частичках пыли или мельчайших капельках воды. Так формируется естественный бактериальный аэрозоль, который перемещается в воздухе в горизонтальном и вертикальном направлениях. Воздух постоянно обогащается различной микрофлорой, попадающей в него с поверхности почвы и водоемов.

Микроорганизмы, находящиеся в воздухе, относятся, в основном, к сапрофитным видам, причем в большинстве они представлены споровыми палочками, пигментными бактериями, грибками и плесенями.

Попавшие в воздух микробы в состоянии бактериального аэрозоля способны сохранять жизнеспособность от нескольких часов до несколько суток, а в отдельных случаях до несколько месяцев. На сроки выживания бактерий в аэрозолях влияют температура и влажность воздуха, солнечная и ультрафиолетовая радиация и другие причины. Воздушный путь передачи заразных микроорганизмов является одним из наиболее опасных. 
Доказано широкое распространение аэрогенных инфекций, которые по своему удельному весу занимают первое место в инфекционной патологии. Поэтому в их профилактике важную роль играет санитарнобактериологический контроль над состоянием воздушной среды.

Обсемененность скорлупы инкубационных яиц в яйцескладе определяли чашечным методом Коха, который заключается в следующем: стерильные чашки Петри с посевами тест-бактерий помещали в специальную камеру, куда подавалась озоновоздушная смесь из лабораторного генератора озона барьерного типа. В качестве среды культивирования использовали питательный агар производства ООО НПП «ПанЭко».

В каждую чашку вносили по 0,1 мл микробной суспензии, содержащей 1000 микробных клеток, которую распределяли по всей поверхности агара. После этого посевы подвергали озонированию. При этом были испытаны концентрации озона 25, 12 и 7 мг/м³ при экспозиции 15, 30, 60 и 120 мин. По окончании озонирования чашки с культурами помещали в термостат при температуре $37^{\circ} \mathrm{C}$ на 24 часа. Результаты опытов оценивали по количеству выросших колоний. Каждое исследование проводили в трех повторностях. В качестве контроля использовались посевы, обработанные общепринятым традиционным препаратом - формальдегидом.

Данные в таблице 1 свидетельствуют о том, что скорлупа инкубационных яиц сильно загрязнена болезнетворными микроорганизмами. Бактериальная обсеменённость инкубационных яиц достигает 410 тыс. бактерий. 
Таблица 1 - Эффективность электротехнологического процесса озонирования яйцескладов птицефабрик.

\begin{tabular}{|c|c|c|}
\hline \multirow{2}{*}{ Период отбора проб } & \multicolumn{2}{|c|}{$\begin{array}{c}\text { Общая бактериальная обсемененность } \\
\text { скорлупы инкубационного яйца }\end{array}$} \\
\cline { 2 - 3 } & тыс. & \% обеззараживания \\
\hline До обработки & $410 \pm 11,3$ & - \\
\hline После обработки & $0,29 \pm 0,05$ & 99,89 \\
\hline
\end{tabular}

После дезинфекции инкубационных яиц озоном общая бактериальная обсемененность скорлупы яиц снизилась на 99,89 \%, что достаточно для профилактики инфекций.

Для того, чтобы стабильно получать положительный эффект от обработки инкубационных яиц озоно-воздушной смесью в яйцескладе птицефабрик необходимо создать равномерную концентрацию озона по всему объему помещения. Для достижения поставленной задачи были проведены исследования распределения озона по помещению яйцесклада в ООО Пксп «Птицевод» Краснодарского края.

Для обоснования требуемого управляющего воздействия для управления распределением концентрации озона в помещении яйцесклада при различных исходных данных была получена математическая модель электротехнологического процесса озонирования яйцескладов птицефабрик.

$$
\left\{\begin{array}{l}
m_{O_{3} Я}=\rho\left(4 \pi\left(\frac{(a \cdot b)^{1,6075}+(b \cdot c)^{1,6075}+(a \cdot c)^{1,6075}}{3}\right)^{\frac{1}{1,6075}} \cdot\left(\frac{5}{6} \cdot N \cdot k_{Я}\right)\right) \\
m_{O_{3} C T}=\rho\left(2 k_{C T}\left(\left(a_{1} \cdot c_{1}\right)+\left(b_{1} \cdot c_{1}\right)+\left(a_{1} \cdot b_{1}\right)\right)\right) \\
C_{O 3 X}=V \sqrt{\frac{q}{4 \pi D t}} \cdot e^{\frac{-x^{2}}{D t}}-\frac{m_{O_{3} Я}+m_{O_{3} C T}}{V} \\
C_{O 3}=\frac{100 \cdot q}{\left(L_{b}+\frac{D S_{\Pi P}}{L_{\Pi I P}}\right)}+a e^{-\left(\frac{L_{B E H T}}{V}+\frac{D S_{\Pi P}}{V L_{I P}}\right)^{t}}-\frac{m_{O_{3} Я}+m_{O_{3} C T}}{V} \\
q=\frac{a_{\mathrm{G} 1}+a_{\mathrm{G} 2} P_{\mathrm{Py}}+a_{\mathrm{G} 3} t_{C}+a_{\mathrm{G} 4} P_{\mathrm{Py}} t_{C}+a_{\mathrm{G} 5} t_{\mathrm{C}}^{2}+a_{\mathrm{G} 6}\left(P_{\mathrm{Py}} t_{C}\right)^{2}}{C_{O 3 X}} \\
P_{P У}=\left(I_{P Y}-I_{P У 3}\right) \cdot U_{P У \Gamma}
\end{array},\right.
$$


где, $q$ - расход озона, м³/ч; $L_{B E н т}-$ вентиляционный расход, м $^{3} /$; $D$ коэффициент диффузии озона м²/ч; $S_{П Р}$ - площадь открытого проема, $\mathrm{M}^{2} ; L_{\Pi P}$ - характерное расстояние от электроозонатора до открытого проема, м; $V$ - объем помещения, м $^{3} ; a, b, c$ - полуоси эллипсоида м; $k_{Я}$ - коэффициент поглощения озона яйцами $(k=0,0001) ; N-$ количество яиц, шт.; $a_{1}, b_{1}, c_{1}$ - стороны параллелепипеда (длина, ширина и высота помещения соответственно), м; $k_{C T}$ - коэффициент поглощения озона стенами $\left(k_{C T}=0,042\right) . m_{O_{3}}$ - масса озона, поглощенная яйцом, мг; $m_{O_{3 C T}}-$ масса озона, поглощенная стенами, мг; $G_{O 3}-$ производительность разрядного устройства по озону, мг/с; $t_{C}$ - температура стекла диэлектрических барьеров, ${ }^{\circ} \mathrm{C} ; P_{P У}-$ мощность разрядного устройства, Вт; $a_{G 1}, a_{G 2}, \ldots, a_{G 6}$ - коэффициенты модели; $U_{P У Г}$ - напряжение горения разряда для используемого РУ; $I_{P У}-$ средний ток, при котором рассчитывается мощность, мА; $I_{P У з}-$ ток зажигания разряда, мА;

Для подтверждения разработанной математической модели в яйцескладе был установлен электроозонатор с параметрами, заявленными при математическом моделировании. Схема проведения эксперимента представлена на рисунке 3.

Эксперимент проводился следующим образом. Вдоль всего яйцесклада от газоанализатора «Циклон - 5.41» 4 был протянут шланг для забора проб воздуха 3. При закрытых дверных проёмах включали электроозонатор 1. Через час его работы путём постепенного вытягивания шланга 3 из помещения яйцесклада через каждый метр измеряли концентрацию озона. Количество яиц - 50000 шт. 


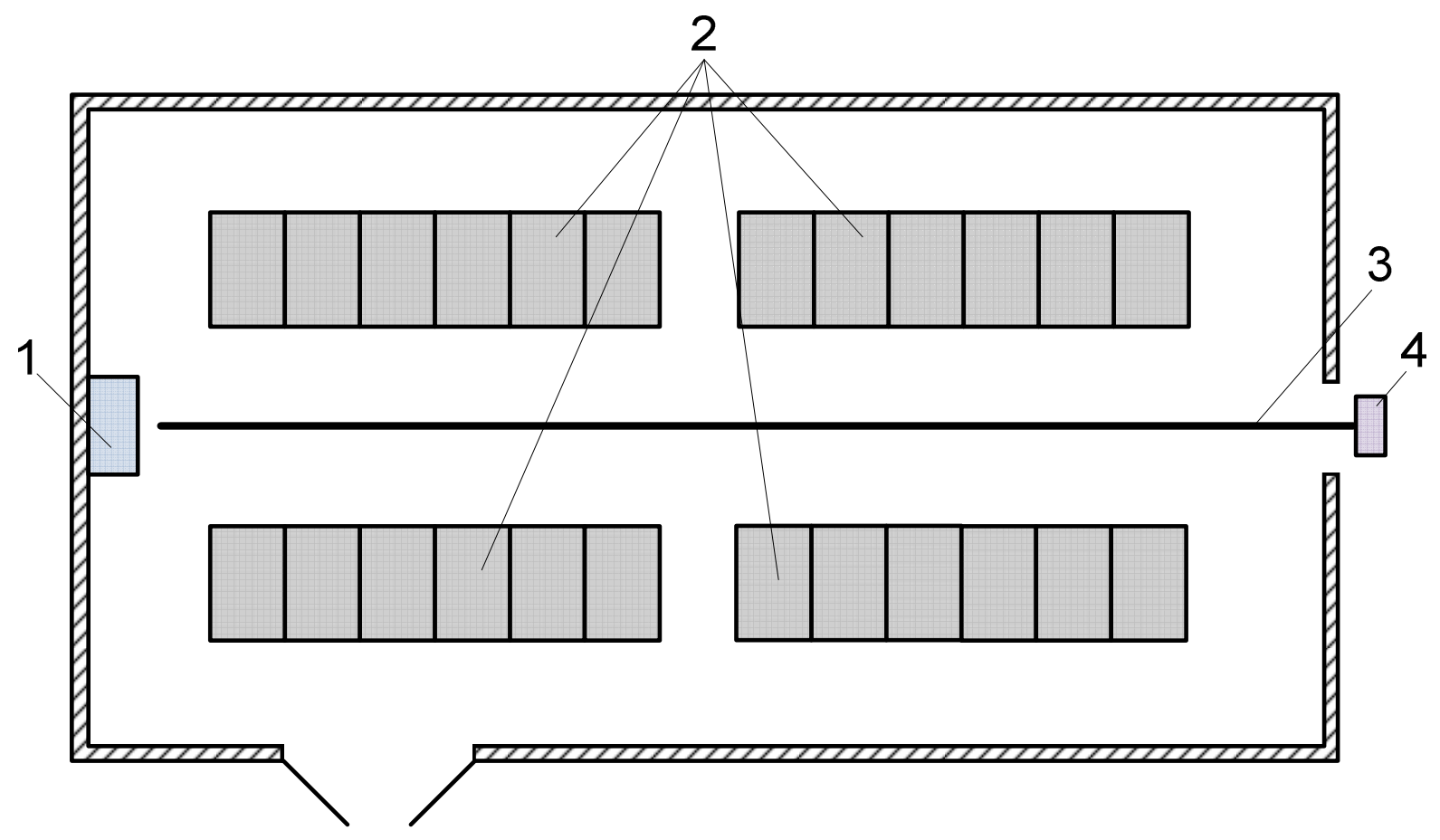

Рисунок 3 - Схема эксперимента: 1 - электроозонатор, 2 - контейнеры с яйцами, 3 - шланг забора проб воздуха, 4 - газоанализатор «Циклон $5.41 »$.

По полученным экспериментальным данным (табл. 3), а также по результатам математического моделирования были построены графики, представленные на рисунке 4.

Таблица 3 - Экспериментальные данные распределения озона по помещению яйцесклада

\begin{tabular}{|c|c|}
\hline Расстояние, & Концентрация озона, мг $/ \mathrm{M}^{3}$ \\
\hline 0 & 19,8 \\
\hline 1 & 19,5 \\
\hline 2 & 18,6 \\
\hline 3 & 16,4 \\
\hline 4 & 14,9 \\
\hline 5 & 11,1 \\
\hline 6 & 9,2 \\
\hline 7 & 6,8 \\
\hline 8 & 3 \\
\hline 9 & 1,1 \\
\hline 10 & 0,2 \\
\hline
\end{tabular}


Графики (рис. 3) подтверждают полученную математическую модель. Установлено, что сходимость теоретических и экспериментальных

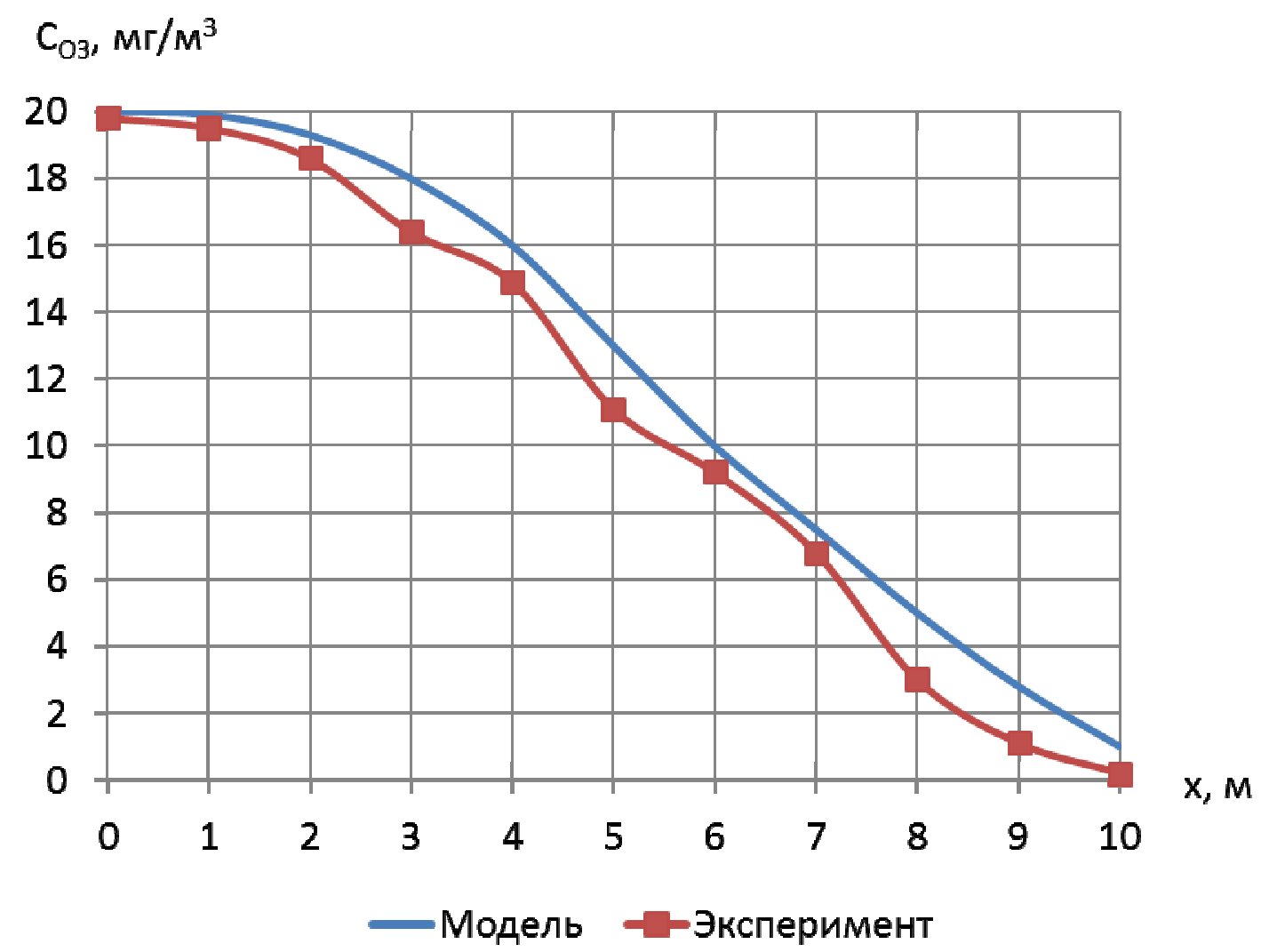

исследований составила $93 \%$.

Рисунок 3 - Графики сравнения теоретических и экспериментальных данных распределения концентрации озона по помещению яйцесклада.

В результате производственных испытаний был апробирован разработанный электротехнологический процесс озонирования яйцескладов птицефабрик. В ходе эксперимента было задействовано 35000 яиц. Размеры яйцесклада $10 \times 7 \times 3$ м. Расположение электроозонатора потолочное в центре яйцесклада. Продолжительность работы электроозонатора составила 118 минут (8 минут - длительность переходного процесса +110 минут работы). Измерение концентрации озона производилось непосредственно у второго датчика концентрации 
озона, который располагался на полу под электроозонатором и находился на расстоянии 2,7 м от него (0,3 м - высота электроозонатора).

Результаты эксперимента по исследованию разработанного электротехнологического процесса озонирования яйцескладов птицефабрик представлены на рисунке 4 и в таблице 4. Динамическая ошибка и коэффициент перерегулирования не превышают допустимого значения, что является необходимым условием для равномерного распределения озона по помещению яйцесклада.

Обобщённый интегральный среднеквадратичный показатель $(\mathrm{J}=10,6 \%)$ снижен на $22,1 \%$ по сравнению с вариантом без регулирования $(\mathrm{J}=32,7 \%)$, что говорит о достаточно качественном регулировании распределения концентрации озона в яйцескладе и удовлетворяет предъявленному допустимому значению данного показателя (не более $15 \%)$.

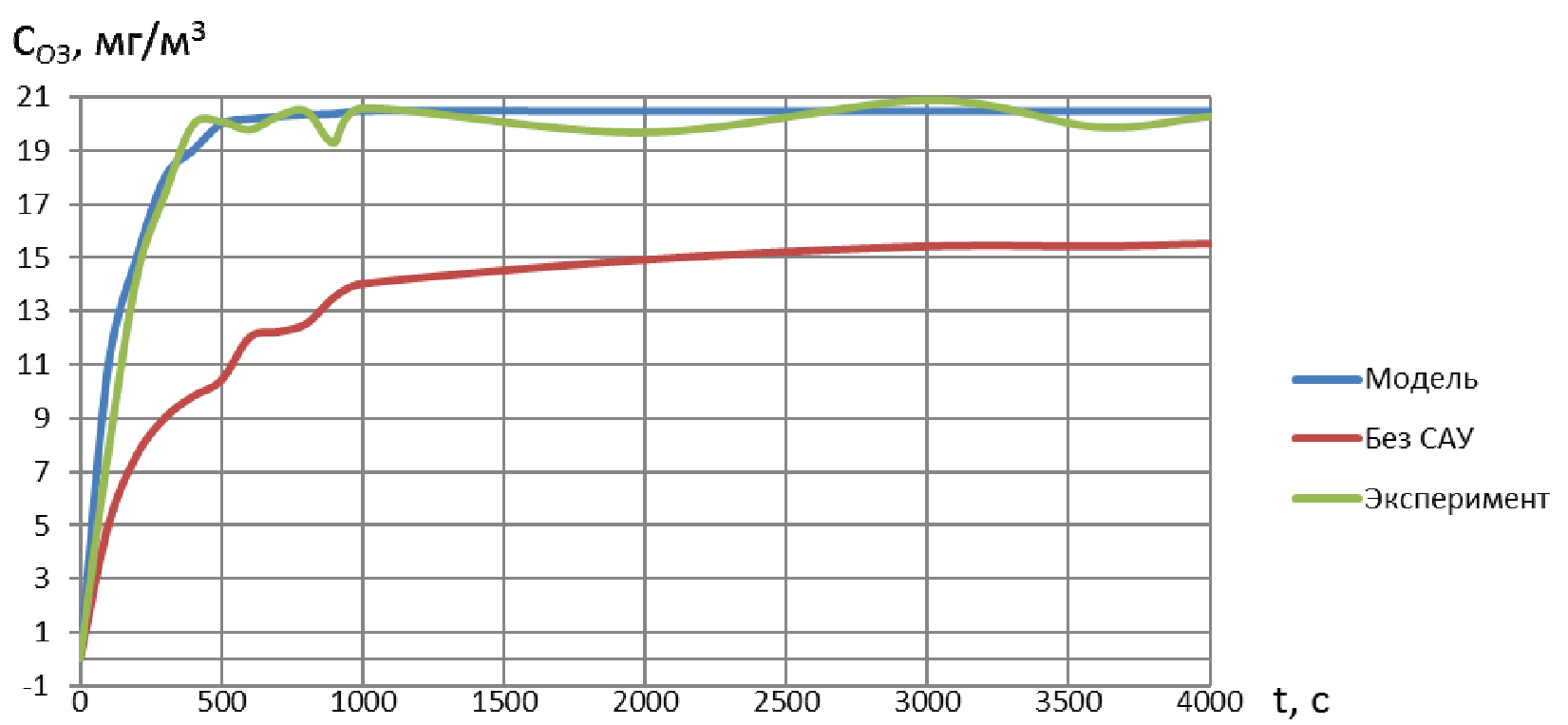

Рисунок 4 - Графики проверки адекватности разработанного электротехнологического процесса озонирования яйцескладов птицефабрик 
Таблица 4 - Полученные показатели качества, разработанного электротехнологического процесса озонирования яйцескладов птицефабрик

\begin{tabular}{|l|c|c|c|}
\hline \multicolumn{1}{|c|}{ Показатели } & С регулированием & $\begin{array}{c}\text { Без } \\
\text { регулирования }\end{array}$ & $\begin{array}{c}\text { Допустимые } \\
\text { значения }\end{array}$ \\
\hline Время регулирования & 8 мин & - & $<30$ мин \\
\hline Динамическая ошибка & 0,9 & $-4,5$ & 1 \\
\hline $\begin{array}{l}\text { Коэффициент } \\
\text { перерегулирования, \% }\end{array}$ & 4,5 & 22,5 & 20 \\
\hline $\begin{array}{l}\text { Обобщённый интегральный } \\
\text { среднеквадратичный } \\
\text { показатель, \% }\end{array}$ & 10,6 & 32,7 & не более $15 \%$ \\
\hline
\end{tabular}

Определены дозы для качественной обработки яиц озоном для зон с количеством яиц равным 35000 штук (табл. 5).

Таблица 5 - Дозы обработки яиц озоном

\begin{tabular}{|c|c|}
\hline Концентрация озона, мг/м & \\
\hline 20 & Время обработки, мин \\
\hline 15 & 110 \\
\hline 10 & 125 \\
\hline 5 & 240 \\
\hline
\end{tabular}

Проведённые производственные испытания показали снижение микробной обсеменённости при использовании разработанного электротехнологического процесса озонирования яйцескладов птицефабрик на 99,89\%. Это объясняется созданием равномерного поля концентрации озона по помещению яйцесклада.

\section{ЗАКЛЮЧЕНИЕ}

В результате экспериментальных исследований подтверждена полученная математическая модель распределения озона по помещению яйцесклада. Относительные погрешности экспериментальных значений от теоретических составляют 7\%. В результате производственных испытаний установлены параметры качества, разработанного 
электротехнологического процесса озонирования яйцескладов птицефабрик: время регулирования -8 минут, динамическая ошибка $-0,9$, коэффициент перерегулирования - 4,5\%, обобщённый интегральный среднеквадратичный показатель - 10,6\%. Полученные данные свидетельствуют о качественном регулировании распределения концентрации озона в яйцескладе. Проведённые производственные испытания показали снижение микробной обсеменённости при использовании разработанного электротехнологического процесса озонирования яйцескладов птицефабрик.

\section{Список литературы}

1. Бородин И.Ф. Совершенствование предынкубационной обработки куриных яиц / И.Ф. Бородин, В.Ф. Сторчевой // Техника в сел. хоз-ве. -2002. -№ 2. -С. 32-33.

2. Возмилов А.Г. Электроочистка и электрообеззараживание воздуха в промышленном животноводстве и птицеводстве. Автореферат дис. на соиск. уч. степ. д.т.н. Челябинск: ЧеГАУ, 1993. - 37 с.

3. Горячий И.В. Озоно-воздушная обработка посевного материала и плодовых тел гриба / И.В. Горячий, Г.П. Стародубцева, В.И. Хайновский // Механизация и электрификация сельского хозяйства. 2008. № 12. С. 12-14.

4. Донсков А.П. Современные технологии в камерах газации инкубационных яиц / А.П. Донсков, А.А. Гончаров, А.П. Волошин // Международное научное периодическое издание по итогам Международной научно-практической конференции: «Новая наука: современное состояние и пути развития»: / в 4 ч. Ч.3 - Стерлитамак: РИЦ АМИ, 2016. - 238 с. С. 62-64.

5. Ксенз Н. В. Использование электроозонированного воздуха в сельскохозяйственном производстве / Н. В. Ксенз, И. Ф. Бородин // Техника в сел. хозве. - 1993. - № 3. - С. 13-14.

6. Ксенз Н.В. Электроозонирование воздушной среды. Зерноград, 1991, 171с.

7. Лытнев А.С. Результаты экспериментальных исследований модернизированной конструкции разрядного устройства пластинчатого типа / А.С. Лытнев, А.П. Волошин // Материалы VI международной научно-практической конференции «Актуальные проблемы энергетики АПК»: / Под общ. ред. Трушкина В.А. - Саратов: ООО «ЦеСАин», 2015. - 327 с. С. 30-33.

8. Нормов Д.А. Электроозонные технологии в сельскохозяйственном производстве / Д.А. Нормов, И.Ф. Бородин // М.: «Вестник Российской академии сельскохозяйственных наук» №1, 2009.-С 57-59.

9. Николаенко С.А. Параметры системы стабилизированного электроозонирования ульев при лечении бактериозов пчел. Диссертация. Краснодар: КубГАУ, 2010. - 180 с.

10. Овсянников Д.А. Учебное пособие для практических занятий в примерах по дисциплине «Планирование и обработка результатов исследований»: учеб. пособие / Д.А. Овсянников, С.А. Николаенко, Д.С. Цокур, А.П. Волошин // -Краснодар, 2014. -76 с.: ил. 
11. Оськин С.В. Электротехнологии в сельском хозяйстве: учебник для студентов вузов / С.В. Оськин. - Краснодар: КубГАУ, 2016. - 501с.

12. Пат. РФ № 2417159, МПК С2 С01B13/11 (2006.01) Электроозонатор / Д.А. Овсянников, С.А. Николаенко, С.С. Зубович, А.П. Волошин, Д.С. Цокур; заявитель и патентообладатель КГАУ. - № 2009126863 заявл. 13.07.2009; опубл. 27.04.2011. Бюл. № $2 .-5 \mathrm{c}$.

13. Пат. РФ № 2429192, МПК С2 С01B13/11 (2006.01) Электроозонатор / Д.А. Овсянников, С.А. Николаенко, С.С. Зубович, А.П. Волошин, Д.С. Цокур; заявитель и патентообладатель КГАУ. - № 20091330067 заявл. 2.09.2009; опубл. 20.09.2011. Бюл. № 26. -6 c.

14. Свид. РФ № 2010620348. Зависимости технологических, электрических и энергетических параметров электроозонатора от температуры нагрева диэлектрических барьеров и напряжения питания / Д.А. Овсянников, С.А. Николаенко, С.С. Зубович, А.П. Волошин, Д.С. Цокур; заявитель и правообладатель КГАУ. - № 2010620203 заявл. 11.05.2010; опубл. 28.07.2010. - 32 с.

\section{References}

1. Borodin I.F. Sovershenstvovanie predynkubacionnoj obrabotki kurinyh jaic / I.F. Borodin, V.F. Storchevoj // Tehnika v sel. hoz-ve. -2002. -№ 2. -S. 32-33.

2. Vozmilov A.G. Jelektroochistka i jelektroobezzarazhivanie vozduha $v$ promyshlennom zhivotnovodstve i pticevodstve. Avtoreferat dis. na soisk. uch. step. d.t.n. Cheljabinsk: CheGAU, 1993. - 37 s.

3. Gorjachij I.V. Ozono-vozdushnaja obrabotka posevnogo materiala i plodovyh tel griba / I.V. Gorjachij, G.P. Starodubceva, V.I. Hajnovskij // Mehanizacija i jelektrifikacija sel'skogo hozjajstva. 2008. № 12. S. 12-14.

4. Donskov A.P. Sovremennye tehnologii v kamerah gazacii inkubacionnyh jaic / A.P. Donskov, A.A. Goncharov, A.P. Voloshin // Mezhdunarodnoe nauchnoe periodicheskoe izdanie po itogam Mezhdunarodnoj nauchno-prakticheskoj konferencii: «Novaja nauka: sovremennoe sostojanie i puti razvitija»: / v 4 ch. Ch.3 - Sterlitamak: RIC AMI, 2016. - 238 s. S. $62-64$.

5. Ksenz N. V. Ispol'zovanie jelektroozonirovannogo vozduha $\mathrm{v}$ sel'skohozjajstvennom proizvodstve / N. V. Ksenz, I. F. Borodin // Tehnika v sel. hoz-ve. 1993. - № 3. - S. 13-14.

6. Ksenz N.V. Jelektroozonirovanie vozdushnoj sredy. Zernograd, 1991, 171s.

7. Lytnev A.S. Rezul'taty jeksperimental'nyh issledovanij modernizirovannoj konstrukcii razrjadnogo ustrojstva plastinchatogo tipa / A.S. Lytnev, A.P. Voloshin // Materialy VI mezhdunarodnoj nauchno-prakticheskoj konferencii «Aktual'nye problemy jenergetiki APK»: / Pod obshh. red. Trushkina V.A. - Saratov: OOO «CeSAin», 2015. - 327 s. S. 30-33.

8. Normov D.A. Jelektroozonnye tehnologii v sel'skohozjajstvennom proizvodstve / D.A. Normov, I.F. Borodin // M.: «Vestnik Rossijskoj akademii sel'skohozjajstvennyh nauk» №1, 2009.-S 57-59.

9. Nikolaenko S.A. Parametry sistemy stabilizirovannogo jelektroozonirovanija ul'ev pri lechenii bakteriozov pchel. Dissertacija. Krasnodar: KubGAU, 2010. - 180 s.

10. Ovsjannikov D.A. Uchebnoe posobie dlja prakticheskih zanjatij v primerah po discipline «Planirovanie i obrabotka rezul'tatov issledovanij»: ucheb. posobie / D.A. Ovsjannikov, S.A. Nikolaenko, D.S. Cokur, A.P. Voloshin // - Krasnodar, 2014. -76 s.: il. 
11. Os'kin S.V. Jelektrotehnologii v sel'skom hozjajstve: uchebnik dlja studentov vuzov / S.V. Os'kin. - Krasnodar: KubGAU, 2016. - 501s.

12. Pat. RF № 2417159, MPK S2 S01V13/11 (2006.01) Jelektroozonator / D.A. Ovsjannikov, S.A. Nikolaenko, S.S. Zubovich, A.P. Voloshin, D.S. Cokur; zajavitel' i patentoobladatel' KGAU. - № 2009126863 zajavl. 13.07.2009; opubl. 27.04.2011. Bjul. № 2. $-5 \mathrm{~s}$.

13. Pat. RF № 2429192, MPK S2 S01V13/11 (2006.01) Jelektroozonator / D.A. Ovsjannikov, S.A. Nikolaenko, S.S. Zubovich, A.P. Voloshin, D.S. Cokur; zajavitel' i patentoobladatel' KGAU. - № 20091330067 zajavl. 2.09.2009; opubl. 20.09.2011. Bjul. № 26. $-6 \mathrm{~s}$.

14. Svid. RF № 2010620348. Zavisimosti tehnologicheskih, jelektricheskih i jenergeticheskih parametrov jelektroozonatora ot temperatury nagreva dijelektricheskih bar'erov i naprjazhenija pitanija / D.A. Ovsjannikov, S.A. Nikolaenko, S.S. Zubovich, A.P. Voloshin, D.S. Cokur; zajavitel' i pravoobladatel' KGAU. - № 2010620203 zajavl. 11.05.2010; opubl. 28.07.2010. - $32 \mathrm{~s}$. 